\title{
OXYGEN DISSOCIATION CURVES IN SICKLE CELL ANEMIA AND IN SUBJECTS WITH THE SICKLE CELL TRAIT
}

\author{
BY MARGARET R. BECKLAKE, S. B. GRIFFITHS, M. MCGREGOR, H. I. GOLDMAN, \\ AND J. P. SCHREVE \\ (From the Cardiopulmonary Unit of the Council for Scientific and Industrial Research, De- \\ partment of Medicine, University of the Witwatersrand and from the South African \\ Institute for Medical Research, Johannesburg, South Africa)
}

(Submitted for publication November 16, 1953; accepted January 22, 1954)

In view of the well recognized differences between sickle and normal hemoglobin $(1,2)$, it was thought that a comparative study of the affinities of sickle and normal hemoglobin for oxygen as shown by the oxyhemoglobin dissociation curve would be of interest.

\section{MATERIAL AND METHODS}

Material: A large number of African blood donors were tested for the sickling phenomenon using the sodium hydrosulphite technique (3).

All donors were healthy mine laborers acclimatized to manual work on the Witwatersrand Goldfields. Of the seven subjects studied with the sickle cell trait, two came from Angola, two from Nyasaland and one each from Portuguese East Africa and Tanganyika. The seventh subject was a South African born Indian. One of the cases of sickle cell anemia studied has been described in greater detail elsewhere by Altmann (4). The three other cases of anemia were South African born Indian children all over 4 years of age whose grandparents came from Surat, near Bombay. Controls were selected from European hospital patients admitted for unrelated complaints. All cases of the trait studied had been resident at the altitude of Johannesburg ${ }^{1}$ for a minimum of 10 weeks. The cases of anemia were all permanent residents of Johannesburg.

Method: Arterial blood was drawn directly into heparinized syringes. Twelve ml. samples were equilibrated in tonometers of approximately $90 \mathrm{ml}$. capacity for $20 \mathrm{~min}$ utes at $37^{\circ} \mathrm{C}$. with gas mixtures containing nitrogen, carbon dioxide and oxygen in varying amounts so as to give three or four points on the dissociation curve. The carbon dioxide was maintained at a gas tension of approximately $34 \mathrm{~mm} . \mathrm{Hg}$ which is the average normal alveolar $\mathrm{CO}_{2}$ tension for this altitude ${ }^{1}$ (5). After equilibration the blood samples were stored in syringes at approximately $4^{\circ} \mathrm{C}$. until they were analyzed on a Van Slyke-Neill manometric apparatus. Analyses were completed in duplicate within ten hours of drawing the samples and were required to agree within .1 vols. per cent.

15780 feet above sea level.
The gas samples were analyzed on a Haldane apparatus with a burette of $10 \mathrm{ml}$. capacity.

The cell $\mathrm{pH}$ of each sample was calculated from the Henderson-Hasselbalch equation with values of cell $\mathrm{pK}$ taken from the nomogram of Keys, Hall, and Barron (6). The cell $\mathrm{pK}$ of the blood of patients with sickle cell anemia could not be derived from this nomogram but was calculated directly from the formula for cell $\mathrm{pK}$ based on work by Stadie and Hawes (7) from which the nomogram of Keys, Hall, and Barron (6) was derived. Correction of the position of curve according to the cell $\mathrm{pH}$ was carried out by use of the factor of Keys, Hall, and Barron (6) to permit comparison of curves at a constant cell $\mathrm{pH}$ (in this case 7.1). The logarithm of the value for $\mathrm{pO}_{2}$ so corrected was plotted against the corresponding percentage saturation and the line of the dissociation curve was drawn to fit the experimental points as closely as possible, assuming it to be parallel to the normal curve described by Dill for blood $\mathrm{pH} 7.4$ (5). From the curve so obtained the $\mathrm{pO}_{2}$ corresponding to a saturation of $\mathbf{5 0}$ per cent was obtained for each individual case. By using these corrections it was hoped that differences in the position of the curves due to differences in cell $\mathrm{pH}$ could be eliminated. However, in view of the fact that the calculations of Stadie are based on observations on normal hemoglobin, it is possible that this correction for cell $\mathrm{pH}$ may be invalid for sickle hemoglobin. For this reason Table I includes for comparison values for $\mathrm{pO}_{2}$ for $\mathrm{Hb}=$ $\mathrm{HbO}_{2}$ at the cell $\mathrm{pH}$ of blood in the tonometers uncorrected to a cell $\mathrm{pH}$ of 7.1 .

TABLE I

\begin{tabular}{|c|c|c|c|}
\hline & Normal & $\begin{array}{c}\text { Sickle } \\
\text { cell } \\
\text { anemia }\end{array}$ & $\begin{array}{c}\text { Sickle } \\
\text { cell } \\
\text { trait }\end{array}$ \\
\hline \multirow{4}{*}{$\begin{array}{l}\text { Number of cases } \\
\mathrm{HbO}_{2} \text { vols. \% (Mean) } \\
\mathrm{pCO}_{2} \text { in tonometers (Mean) } \\
\text { Calculated cell } \mathrm{pH}(6) \\
\text { (Mean) } \\
\mathrm{pO}_{2} \text { for } \mathrm{Hb}=\mathrm{HbO}_{2} \text { at cell } \\
\mathrm{pH} \text { of blood in tonometers } \\
\text { (Mean) } \\
\text { (Mtandard deviation } \\
\mathrm{pO} 2 \text { for } \mathrm{Hb}=\mathrm{HbO}_{2} \text { at cell } \\
\mathrm{pH} \text { of } 7.1 \text { (Mean) } \\
\text { Standard deviation }\end{array}$} & $\begin{array}{c}10 \\
18.95 \\
32.6\end{array}$ & $\begin{array}{c}4 \\
12.55 \\
36.9\end{array}$ & $\begin{array}{c}7^{7} \\
19.95 \\
34.2\end{array}$ \\
\hline & 7.18 & 7.00 & 7.08 \\
\hline & $\begin{array}{c}25.7 \\
\pm 1.10\end{array}$ & $\begin{array}{c}42.6 \\
\pm 5.08\end{array}$ & $\begin{array}{l}28.6 \\
\pm .97\end{array}$ \\
\hline & $\begin{array}{l}26.0 \\
\pm .42\end{array}$ & $\begin{array}{c}40.0 \\
\pm 4.82\end{array}$ & $\begin{array}{l}28.1 \\
\pm .97\end{array}$ \\
\hline
\end{tabular}




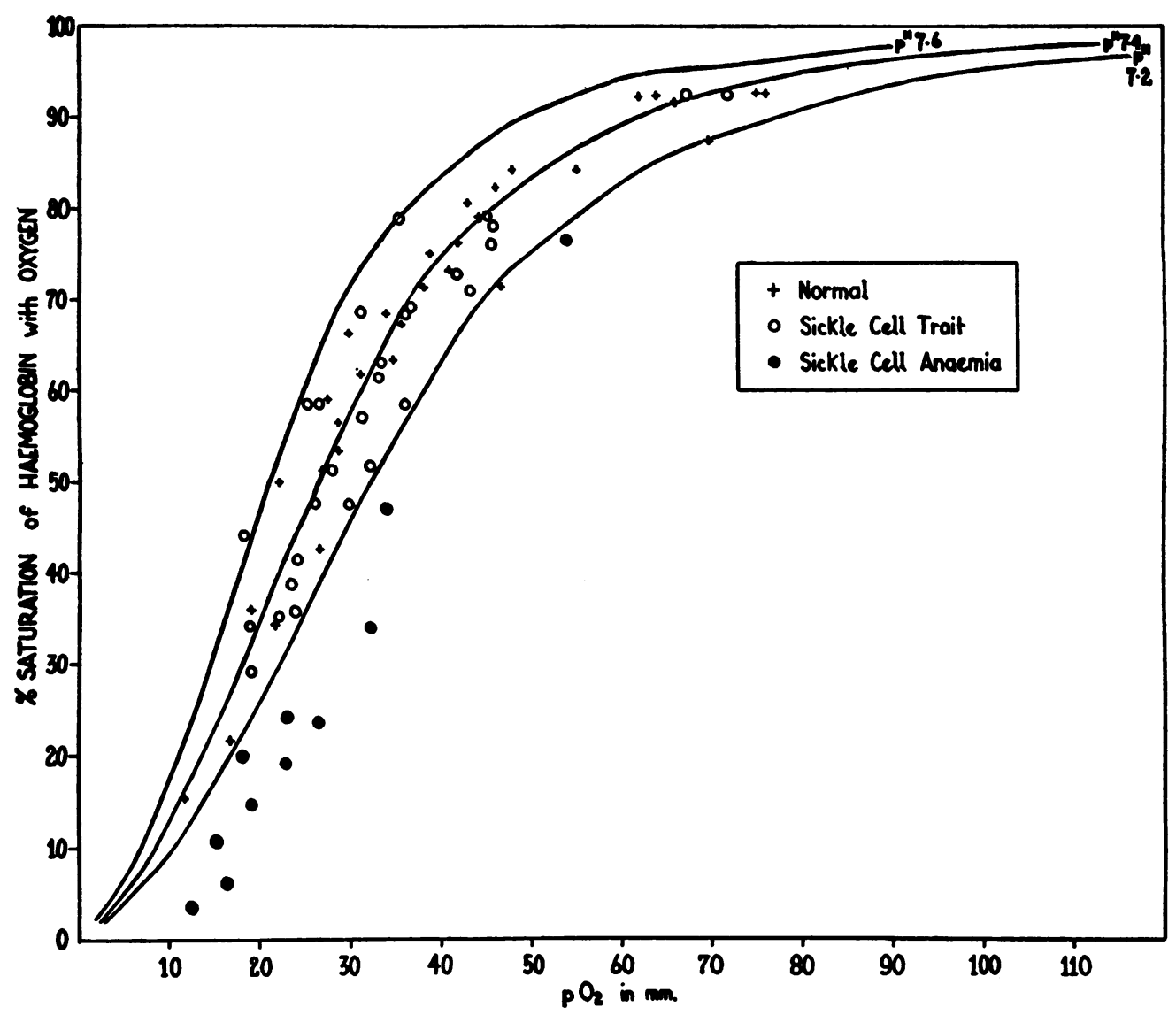

Fig. 1. Illustration of the Experimental Points from Which the Dissociation Curves Were Derived

$\mathrm{pO}_{2}$ values have been corrected to a cell $\mathrm{pH}$ of 7.1. The normal curves for blood $\mathrm{pH}$ of 7.6, 7.4, and 7.2, shown in continuous lines, are taken from the work of Dill (5).

\section{RESULTS}

Results are tabulated in Table I, and are represented graphically in Figure 1 which shows the individual points from which the curves were derived.

The significance of the differences of the mean $\mathrm{pO}_{2}$ for $\mathrm{Hb}=\mathrm{HbO}_{2}$ of normal bloods on the one hand and in cases of sickle cell trait and sickle cell anemia on the other hand has been tested using Student's t test (8). The mean $\mathrm{pO}_{2}$ for $\mathrm{Hb}=$ $\mathrm{HbO}_{2}$ of the sickle anemia bloods is significantly different from the $\mathrm{pO}_{2}$ for $\mathrm{Hb}=\mathrm{HbO}_{2}$ of normal blood ( $p>.01$ ) when considered both at the cell $\mathrm{pH}$ of blood in the tonometers and at a cell $\mathrm{pH}$ of 7.1. The curve of one of the sickle anemias studied showed much less displacement to the right than the others $\left(\mathrm{pO}_{2}\right.$ for $\mathrm{HbO}_{2}$ at cell $\mathrm{pH}$ of blood in tonometers was $30.1 \mathrm{~mm}$.). This case had been admitted to hospital acutely ill in a crisis and had received many transfusions in the course of treatment, so that only about 30 per cent of circulating hemoglobin at the time of study was the patient's own. This no doubt accounts for the much less significant shift in position of this curve compared to curves on the other three cases of anemia studied in whom over 98 per cent of the hemoglobin present was abnormal.

The mean $\mathrm{pO}_{2}$ for $\mathrm{Hb}=\mathrm{HbO}_{2}$ of the cases with the sickle cell trait is also greater than the corresponding value for normal blood both at the cell $\mathrm{pH}$ of blood in the tonometers and at a standard cell $\mathrm{pH}$ of 7.1 but this difference is not statistically significant $(p=.2$ to .1$)$. 


\section{DISCUSSION}

The techniques used in this study have been criticized by Lambertsen, Bunce, Drabkin, and Schmidt (9) whose experiments, using spectrophotometric techniques, suggested that the true dissociation curve for hemoglobin at a blood $\mathrm{pH}$ of 7.4 lies to the left of the curve of Dill (5). Our mean normal curve $\left(\mathrm{pO}_{2}\right.$ for $\mathrm{Hb}=\mathrm{HbO}_{2}=$ $26.0 \mathrm{~mm}$. $\mathrm{Hg}$ ) also lay to the left of Dill's curves $\left(\mathrm{pO}_{2}\right.$ for $\mathrm{Hb}=\mathrm{HbO}_{2}=26.3 \mathrm{~mm}$. $\mathrm{Hg}$ ) though this difference in position does not appear to be of any statistical significance. The altitude at which these studies were carried out (5780 ft. above sea level) may have been the reason for the slight shift to the left in position of our normal curve (6). However, the interest in these results lies not so much in the position of the normal dissociation curve at this altitude as in the difference between its position and that of the cases of sickle cell anemia or trait.

Only one record of the oxygen dissociation curve of whole blood from a case of sickle cell anemia was found in the literature (10). In this report the curve of the case of anemia is shown graphically to be shifted to the right of a normal curve which on scrutiny is found to be in the position of Dill's normal curve at blood $\mathrm{pH}$ of 7.2. It is not clear from the text if the curve of the anemia subject was corrected to the same cell $\mathrm{pH}$ as the normal with which it was compared. The authors concluded that the shift in the position of the curve was not peculiar to the sickle blood but was probably due to anemia and a decrease in the cell $\mathrm{pH}$ coincident with insufficient oxygenation.

Other workers have reported a similar shift to the right of the dissociation curve in various types of anemia even when the cell $\mathrm{pH}$, carefully controlled, is comparable to that of the normal curves used in comparison (11-13). Dill and his coworkers (11) produced evidence to show that in pernicious anemia there was certainly a relative alkalosis of the serum and probably relative acidosis of the cells. These changes they felt were quite sufficient to account for the shift in position of the curve which returned to a normal position when adequate treatment had led to a return to normal in the blood count.

Kennedy and Valtis (13) also found that the oxygen dissociation curve of blood of cases of Ad- disonian anemia and cases of hypochromic anemia lay to the right of that of normal blood, but this shift in position was not demonstrated in cases of hemolytic anemia. They too drew attention to the lowered cell $\mathrm{pH}$ as a factor which may have been responsible for the shift of the curve to the right but concluded that this was not the only factor as some displacement to the right was apparent even when results were corrected to a constant cell $\mathrm{pH}$.

It is quite possible that the lowered cell $\mathrm{pH}$ may have been responsible for some of the displacement of the dissociation curves found in the sickle cell anemia bloods studied here. In support of this, the cell $\mathrm{pH}$ calculated by the method of Keys, Hall, and Barron (6) was lower in the cases of anemia than it was in the normal series (see Table I). As has been mentioned the corrections to a constant cell $\mathrm{pH}$ may not be valid here as they are based on data for normal hemoglobin and may not be applicable to sickle hemoglobin. Thus one may not assume that the corrections applied here ruled out the effects of variations in the cell $\mathrm{pH}$ on the position of the curve. However, it seems most unlikely that a cell $\mathrm{pH}$ so slightly different from the normal should be solely responsible for the striking shift of the curve of sickle anemia blood to the right (13), and some other factor must be contributing to the shift in position.

A factor which may have influenced the position of the curve is, of course, the $\mathrm{pCO}_{2}$. Table I indicates that despite efforts to keep the $\mathrm{pCO}_{2}$ constant in all studies, the mean $\mathrm{pCO}_{2}$ for the experimental points calculated in the cases of sickle cell anemia was higher than the mean $\mathrm{pCO}_{2}$ for the normal group or the group exhibiting the trait. Nevertheless, the studies of Haldane and Priestley (14) make it reasonably certain that a difference of $4.3 \mathrm{~mm}$. $\mathrm{Hg}$ in $\mathrm{pCO}_{2}$ could not on its own account for a shift in dissociation curve of the extent noted in the cases of sickle cell anemia.

On the other hand changes in the cell environment, particularly electrolyte changes, may well have been most important in influencing the position of the curve. Such an explanation could reconcile the results reported here with the studies of Wyman and Allen (15) who showed that the dissociation curve of dialyzed solutions of sickle hemoglobin is no different from the dissociation curve obtained on dialyzed solutions of normal hemoglobin similarly prepared. In other words 
the difference in the oxygen affinities of sickle anemia hemoglobin and normal hemoglobin is apparently only demonstrable when the two types of hemoglobin are studied in their natural plasma environment. The influence of the hemoglobin environment on the oxygen dissociation curve has been previously demonstrated by Wyman, Allen, and Smith (16) who showed that the difference in the oxygen affinities of fetal and normal hemoglobin was due to dialyzable factors. An analogous situation appears to have been demonstrated here in the difference between the oxygen affinities of sickle and normal hemoglobin. The hypothesis that the hemoglobin environment is responsible for the difference in oxygen affinity demonstrated here appears to fit our findings better than the suggestion that the difference in oxygen affinity is due to differences in the inherent properties of the two hemoglobins.

The conclusions to be derived from our studies on sickle trait hemoglobin are confused by the results in one case of sickle cell trait which differed greatly from the other 6 cases. Excluding this one case the mean $\mathrm{pO}_{2}$ for $\mathrm{Hb}=\mathrm{HbO}_{2}$ of sickle trait hemoglobin was significantly different from the mean normal $\mathrm{pO}_{2}$ for $\mathrm{Hb}=\mathrm{HbO}_{2}(\mathrm{p}=>$ $.01)$. When this case is included, the scatter of results makes the difference of no statistical significance $(p=.2$ to .1$)$. On account of the unusual results, this case was studied on three separate occasions within a period of 3 months to make certain that technical errors could not have accounted for the result obtained $\left(\mathrm{pO}_{2}\right.$ for $\mathrm{Hb}=$ $\mathrm{HbO}_{2}$ was $22.8 \mathrm{~mm}$.). Electrophoretic studies on the blood of this case gave results similar to those in the other cases of the sickle cell trait and consequently afforded no reason for the curve of this case being so differently placed from the curves of the other sickle trait blood examined. The rarity of the sickle cell trait in South Africa has made it not possible to determine, by the study of a larger series, if the exceptional case in the present series of 7 must be regarded as significant.

\section{SUMMARY AND CONCLUSIONS}

1. The oxygen dissociation curve of blood from 4 cases of sickle cell anemia studied by the in vitro tonometer method was significantly displaced to the right of the dissociation curve of blood from 10 normal subjects.
2. The oxygen dissociation curve of blood from 7 cases of sickle cell trait studied by the same method showed no such significant displacement.

3. These observations in conjunction with the work of Wyman, Allen, and Smith $(15,16)$ on the oxygen affinity of dialyzed solutions of sickle and normal hemoglobin are consistent with the hypothesis that this difference in oxygen affinity is due to dialyzable factors, i.e., the serum environment of the cell rather than actual differences between the affinity of normal and sickle anemia hemoglobin for oxygen.

\section{ACKNOWLEDGMENTS}

Our thanks are due to Professor G. A. Elliott in whose department the blood gas studies were carried out and for his helpful criticism of the text, to Dr. E. Cluver, Director of the South African Institute for Medical Research, for facilities given, and to Dr. A. Zoutendyk who made available the sickle cell trait blood for study. All electrophoretic studies were performed by Dr. C. J. Anderson of the South African Institute for Medical Research, and he very kindly put us in touch with three of the cases studied. Medical Officers of various Reef Mine Hospitals assisted in giving facilities for study of individual cases, and Dr. G. H. Soni of Johannesburg kindly allowed us to study three of his patients.

\section{REFERENCES}

1. Pauling, L., Itano, H. A., Singer, S. J., and Wells, I. C., Sickle cell anemia-a molecular disease. Science, 1949, 110, 543.

2. Perutz, M. F., and Mitchison, J. M., State of haemoglobin in sickle-cell anaemia. Nature, 1950, 166, 677.

3. Williams, A. W., and Mackey, J. P., Rapid determination of the sickle cell trait by the use of a reducing agent. J. Clin. Path., 1949, 2, 141.

4. Altmann, A., Sickle cell anaemia in a South African born European. Clin. Proc., 1945, 4, 1.

5. Handbook of Respiratory Data in Aviation, 1944. Washington, National Research Council.

6. Keys, A., Hall, F. G., and Barron, E. S. G., The position of the oxygen dissociation curve of human blood at high altitude. Am. J. Physiol., 1936, 115, 292.

7. Stadie, W. C., and Hawes, E. R., Studies on oxygen, acid, and base-combining properties of blood. J. Biol. Chem., 1928, 77, 241.

8. Fisher, R. A., Statistical Methods for Research Workers. London, Oliver and Boyd, 1948.

9. Lambertsen, C. J., Bunce, P. L., Drabkin, D. L., and Schmidt, C. F., Relationship of oxygen tension to hemoglobin oxygen saturation in the arterial blood of normal men. J. Applied Physiol., 1952, 4, 873. 
10. Schriver, J. B., and Waugh, J. R., Studies on a case of sickle cell anaemia. Canad. M. A. J., 1930, 23, 375.

11. Dill, D. B., Bock, A. V., Van Caulaert, C., Folling, A., Hurxthal, L. M., and Henderson, L. J., Blood as a physicochemical system: VII : The composition and respiratory exchanges of human blood during recovery from pernicious anemia. J. Biol. Chem., 1928, 78, 191.

12. Richards, D. W., and Strauss, M. L., Oxy-hemoglobin dissociation curves of whole blood in anemia. J. Clin. Invest., 1927, 4, 105.
13. Kennedy, A. C., and Valtis, D. J., The oxygen dissociation curve in anemia of various types. $\mathrm{J}$. Clin. Invest., 1954, 33, 1372.

14. Haldane, J. S., and Priestley, J. G., Respiration. 2d ed., Oxford, Clarendon Press, 1935.

15. Wyman, J., Jr., and Allen, D. W., Heme interactions in hemoglobin and the basis of the Bohr effect. J. Polymer. Sc., 1951, 7, 499.

16. Allen, D. W., Wyman, J., and Smith, C. A., The oxygen equilibrium of fetal and adult human hemoglobin. J. Biol. Chem., 1953, 203, 81. 